\title{
Stock structure of the English Channel common cuttlefish Sepia officinalis (Linnaeus, 1758) during the reproduction period
}

\author{
Gras Michaël 1, 2, " , Safi Georges 1,2, Lebredonchel Hugo 1,2, Quinquis Jerome 3, Foucher Eric ${ }^{3}$, \\ Koueta Noussithe ${ }^{1,2}$, Robin Jean-Paul ${ }^{1,2}$
}

1 UPMC, MNHN, UCBN, BOREA,CNRS,UMR 7208,IRD 207, F-14032 Caen, France.

2 Univ Caen Basse Normandie, UMR BOREA Biol ORganismes \& Ecosyst Aquat, Esplanade Paix, CS 14032, F-14032 Caen, France.

3 IFREMER, Lab Ressources Halieut, Ave Gen Gaulle,BP 32, F-14520 Port En Bessin, France.

*Corresponding author : Michaël Gras, email address : michael.gras@ymail.com

\begin{abstract}
:
Within the English Channel, the common cuttlefish Sepia officinalis is a semelparous species for which a 2 -year life cycle was exclusively described in the 1980s. In the 1990s, new research indicated that whilst a 2-year life cycle was still evident for females and the large majority of males, a small proportion of males were actually maturing at only 1 year of age. Since 1980, the interest of French and UK fishers for this resource has increased and it is nowadays one of the most important demersal species of the area and is considered to be fully exploited. From the start of the 20th century, fishing effort and sea surface temperatures have increased in the English Channel and have probably impacted the life history traits of S. officinalis. A 2-year sampling programme was undertaken at French landing sites of the English Channel during the reproduction season in 2010 and 2011 to estimate if the proportion of 1 -year-old mature animals has changed. Age determination was carried out by coupling polymodal decomposition and lipofuscin measurement. Size-at-maturity for each year and each sex was estimated by fitting a binomial error GLM. Results highlight that a variable percentage of males and females belonging to the first cohort are mature and that size-at-maturity was lower than that observed in the 1990s. Finally, different parameters, such as temperature and fishing pressure are explored to discuss changes in life history traits suggesting that cuttlefish could be an indicator of the temperature regime shift in the English Channel.
\end{abstract}

Keywords : Sepia officinalis, English Channel, life history traits, maturity, warming, fishing pressure 


\section{INTRODUCTION}

The common cuttlefish, Sepia officinalis (Linnaeus, 1758), is a short lived and is a semelparous cephalopod (Mangold, 1987) distributed from the West African coast (Senegal and Mauritania) to the English Channel and in the Mediterranean Sea. It has a life cycle 
lasting between 1 and 2 years depending on the latitude at which it lives. From West African to the Portuguese coasts, the entire population has a 1 year life cycle (Mangold, 1966; Guerra and Castro, 1988; Coelho and Marthins, 1991). The Bay of Biscay is a transition zone where two different groups were identified; Group I Breeding (GIB), can breed at one year of age (45\% of male specimens and $20 \%$ of female specimens), Group II Breeding (GIIB), breeds at two years of age (Le Goff and Daguzan, 1991; Gauvrit et al., 1997). In the English Channel, life cycle of $S$. officinalis was first described as lasting exclusively two years (BoucaudCamou and Boismery, 1991; Boucaud-Camou et al., 1991). A decade later, Dunn (1999a) found that the entire female population and $96 \%$ of male specimens have a 2 year life cycle (GIIB). The remaining males (4\%) were found to be mature at the age of one year old, constituting a GIB.

However, all these studies based age estimation only on polymodal decomposition of length frequencies. In cephalopods, growth rate is influenced by environmental conditions and presents a high inter-individual variability making this method unaccurate. Various hard structures have been tested for age determination in S. officinalis (Le Goff et al., 1998) but the only consistent results were obtained from statolith daily rings during the juvenile phase (Challier et al., 2002, 2006). However, statolith rings are very difficult to read in S. officinalis and are not usable after 240 days of age (Bettencourt and Guerra, 2001). Above this threshold, some studies proposed to use the concentration of lipofuscin as a proxy of age: lipofuscin is a pigment that accumulates in tissues through the lifetime of some invertebrates (Sheehy et al., 1996; Ju et al., 1999; Bluhm and Brey, 2001). This method has been successfully used in cephalopods to provide a rough estimation of S. officinalis age (Zielinski and Pörtner, 2000; Doubleday and Semmens, 2011).

English Channel population of Sepia officinalis was a non valuable by-catch before the 1980s (Dunn, 1999a). Since then, the increasing price of this species and the depletion of finfish stocks (Royer et al., 2006) lead French and UK fishers to exploit this stock. Landings increased from 4350 tonnes in 1992 to a maximum of 17400 tonnes in 2004 (Gras et al., 2014). During the 2000-2010 decade, an average of 11000 tonnes was landed annually for an average turnover of $€ 20 \mathrm{M}$ (Pierce et al., 2010; Portail CHARM III - Interreg IV, 2012). The English Channel Sepia officinalis was assessed in trial using a depletion model (Dunn, 1999b), a Virtual Population Analysis (Royer et al., 2006) and a two-stage biomass model (Gras et al., 2014). If Dunn (1999b) does not give a clear indication of the stock status, Royer et al. (2006) and Gras et al. (2014) concluded that Sepia officinalis has been fully exploited since the beginnning of the 1990s. Moreover, Gras et al. (2014) showed that S. officinalis abundance decreased during the period 2001-2008 and consequences of the fishing pressure on life history traits should be investigated.

High fishing pressure directly and indirectly affects fish communities and populations. Among the direct effects of high fishing pressure on populations are increased mortality and size selectivity that tend to reduce the proportion of old and large specimens in the population (Smith, 1994). After several years of high exploitation, smaller specimens maturing faster are favoured, leading to decrease mean size and length (or age) at maturity by favouring slow growth and early maturing specimens (Bianchi et al., 2000; Shin et al., 2005; Kantoussan et al., 2009). Observations of such processes have been carried out in various stocks of the NE Atlantic such as the North-Sea herring (Shin and Rochet, 1998; Engelhard and Heino, 2004), the North-Sea plaice (Grift et al., 2003) and the northern cod (Olsen et al., 2004). The English Channel has been trawled for over 200 years and from the beginning of the twentieth century to date, the fishing pressure has increased considerably (Hawkins et al., 2003). According to Guenette and Gascuel (2012), the French fishing effort displayed in the Celtic Sea and the Bay of Biscay (including western English Channel, ICES division VIIe where $S$. officinalis overwinters and is exploited by offshore trawlers) has been multiplied by 10 
between 1950 and 2010. In the English Channel, the number of trawling vessels (coming from France and UK) who share the demersal resources has increased from 450 vessels in 2000 to almost 800 ten years later (Portail CHARM III - Interreg IV, 2012). Finally, a compilation of French and UK data used to derive abundance indices (Gras, 2013; Gras et al., 2014) shows an increase of the trawling effort from 572,000 hours in 1992 to an average of 900,000 $\mathrm{h}$ for the period 2003-2007.

In addition to the fishing pressure, climate variations (including global warming which is made of natural and anthropogenic components) are also known to influence the abundance and spatial distribution of marine species (Beaugrand and Reid, 2003; Hawkins et al., 2003; Beaugrand, 2009). According to the data collected by the Marine Biological Association of the United Kingdom (MBA), warming of the English Channel has been highlighted throughout the twentieth century (Southward and Roberts, 1987). Between 1986 and 2006, Saulquin and Gohin (2010) estimated this warming between 0.5C in the southern part of the Channel and $1.5 \mathrm{C}$ in its northern part. This warming has lead to modifications in phytoplankton assemblages, fish larval abundances and pelagic fish abundances (Southward et al., 1988). Moreover, a decline in community level, average length and length-at-maturity in demersal communities has been observed, suggesting that fish assemblages become dominated by species maturing faster and reproducing at a shorter length (Hawkins et al., 2003). Due to their short life cycle and their high metabolic rate, cephalopods are assumed to be very sensitive to environmental warming (Pierce et al., 2010).

In the context of high fishing pressure and global warming observed between the end of the 1980s and the end of the 2000s in the English Channel, this work aims to establish wether modifications in the life cycle of the $S$. officinalis exist. By focusing on the stock structure in the reproduction period, we would like to highlight if the percentage of one-year old mature males observed by Dunn (1999a) has changed and if a percentage of one-year old mature females exists. To achieve this goal, a two-year sampling programme was carried out in spring at French landing sites within the English Channel. Length frequencies associated with measurement of lipofuscin were used to disentangle the two cohorts and estimate the percentage of mature one-year olds. The size-at-maturity and the Gonado Somatic Index estimated are compared with results previously published (Dunn, 1999a). Results obtained are finally discussed in the framework of the environmental pressures exerted on the S. officinalis population inhabiting the English Channel.

\section{MATERIAL AND METHODS}

\section{Study area: the English Channel}

The English Channel is situated between the N-E Atlantic and the North Sea. Following the International Council for the Exploration of the Sea (ICES) two divisions exist, VIId to the East and VIIe to the West. The western English Channel is characterised by a maximum depth of around $170 \mathrm{~m}$ and is strongly influenced by Atlantic waters. With a minimum temperature $>10 \mathrm{C}$ in winter, this area has favourable conditions for the overwintering of S. officinalis (Wang et al., 2003). The eastern English Channel (ICES division VIId) is characterised by shallow waters, maximum depth of $50 \mathrm{~m}$, and a homogeneous water column. Winter sea temperature in this part of the Channel can reach as low as $5 \mathrm{C}$, making it unsuitable for overwintering of S. officinalis (Pingree, 1980; Boletzky, 1983).

Previously described migration cycle of S. officinalis within the English Channel

In the English Channel, $S$. officinalis hatch inshore at the beginning of summer (Fig. Erreur ! Source du renvoi introuvable.). After spending the entire summer feeding inshore, they migrate offshore to overwinter in the central western English Channel (Boucaud-Camou and Boismery, 1991; Dunn, 1999a; Royer et al., 2006) where sea bottom temperature is favourable (Wang et al., 2003). The following summer is also spent feeding inshore. At the 
end of this second summer, male specimens finish their maturation (in approximately September). In October, they perform their second offshore migration to the wintering grounds where female specimens complete their maturation. The final migration is performed at approximately 20 months old to reach the inshore spawning zones. Mass mortality of sexually mature adults occurs after the reproduction period (Boucaud-Camou and Boismery, 1991; Dunn, 1999a; Royer et al., 2006).

\section{Figure Erreur ! Source du renvoi introuvable.}

\section{Sample collection}

Samples of S. officinalis were collected from 3 French landing sites along the English Channel coastline in spring 2010 and 2011. Specimens were caught by trawlers or trap fishers in the Normano-Breton Gulf (ICES rectangles 26E8 and 27E8) and in the Bay of Seine (ICES rectangles 27E9 and 28E9). In 2010, from April 12 to July 9, 734 specimens (395 males, 339 females) were collected in Erquy, Cherbourg and Port-en-Bessin landing sites. In 2011, from April 5 to June 30, 655 specimens (444 males and 211 females) were collected in Port-enBessin and Cherbourg landing sites. The sex ratio was tested using a chi-square test.

\section{Biometry dissection and sex determination}

The Dorsal Mantle Length (DML) of each specimen was measured to the smallest whole $\mathrm{cm}$ and length frequencies were represented on 4 histograms, one per sex and per year. Breaks are defined every $\mathrm{cm}$, immature specimens are represented in white; mature animals are represented in grey. An attempt was made to fit two gaussian models associated with a mixing effect to the two cohorts. If the model fitted well the first cohort, due to its shape, it was not possible to fit it to the second cohort. A rough threshold between the first and second cohort is thus defined by the least numerous length class after the first mode. However, due to the high inter-individual variability of the growth rate in S. officinalis (Challier et al., 2002, 2005), this criteria cannot be used on its own to determine which cohort a particular specimen belongs to. The measurement of Lipofuscin (age pigment accumulated in tissues; Zielinski and Pörtner, 2000; Doubleday and Semmens, 2011) was used in this work to give a second indicator of age estimation. Fresh total Body Weight (BW) and Gonad Weight (GW) were also measured for each specimen.

The mantle of each specimen was opened by a ventral incision to determine the sex and maturity stage using the macroscopic scale developed in the framework of the international Workshop on Sexual Maturity Staging of Cephalopods (WKMSCEPH; ICES, 2010). Six maturity stages are described from undetermined to spent (post-reproduction) for each sex. In female specimens, maturity stages are mainly defined using oocyte size and development of the Nidamental Glands (NG). In male specimens, maturity stages are defined using testis size and spermatophore position in the Spermatophoric Complex (SC). This international scale is based on the same number of stages and the same criteria as the one developed by Dunn (1999a). Mantle tissue samples were collected from a subsample of specimens to measure lipofuscin concentrations. Tissue samples were kept frozen in liquid nitrogen until analysis to avoid tissue degradation and transported to the laboratory to be analysed.

\section{Lipofuscin measurement}

Lipofuscin was measured according to Zielinski and Pörtner (2000). Mantles of $S$. officinalis were ground under liquid nitrogen and homogenized in a chloroform-methanol mixture $(1: 2, \mathrm{v} / \mathrm{v})$. After centrifugation for $10 \mathrm{~min}$ at $2000 \mathrm{~g}$, lipofuscin was found in the chloroform phase. In this phase an emission spectrum between 350 and $550 \mathrm{~nm}$ was obtained at an excitation wavelength of $350 \mathrm{~nm}$ using a Mithras LB940 fluorimeter (Berthold, Thoiry, France). The luminescence of the sample was determined at the maximum emission at 420 $\mathrm{nm}$. Lipofuscin concentrations were expressed as relative fluorescence intensity according to Hill and Womersley (1991), using $0.1 \mu \mathrm{g}$ quinine per ml $1 \mathrm{~N} \mathrm{HSO}$ as a standard.

In a first step, we tested the applicability of lipofuscin concentrations to fish market 
samples of $S$. officinalis by measuring post-mortem variability over the 3 days following the death. A mantle was sampled on one living animal and lipofuscin was measured on the fresh tissue. The tissue was then kept on ice during the following 3 days. A large piece of mantle was taken every $24 \mathrm{~h}$ randomly on the mantle and used to perform replicated measures of lipofuscin. Differences were tested using an ANOVA. In a second step, lipofuscin concentrations were measured on 2 subsamples. A subsample of 11 immature specimens was taken from the first cohort (DML ranging 10-13 cm and assumed to be one-year olds as they are immature) and a subsample of 17 mature specimens was taken from group which length is highly over the boundary between the two cohorts (DML ranging 20-31 cm and therefore assumed to be two-year olds). This experiment describes inter-cohort differences in lipofuscin concentrations. Finally, results of lipofuscin concentration measured from the smallest mature specimens ( 2 of $11 \mathrm{~cm}$ DML and 1 of $13 \mathrm{~cm}$ DML) were used in a Student Test to estimate the probability of each small mature specimen to belong to each cohort.

\section{Size-at-maturity estimation}

The maturity stage of each specimen, observed in each length class, was used to fit a binomial error Generalized Linear Model (GLM) to estimate size-at-maturity. Specimens were considered as mature when they reached the "Maturing stage" (2b), assuming that if they are maturing during the spring, they will become mature and able to breed and spawn before the end of the reproduction season in late summer.

\section{Gonado-Somatic Index}

An index of sexual development was computed with the Gonado-Somatic Index (GSI):

$$
G S I=\frac{G W}{B W-G W}
$$

GSI is a proxy of the energy allocated by the specimen to reproduction to the detriment of somatic growth. This index is a quantitative measure of sexual maturity and the relationship between GSI and DML complements the estimation of size-at-maturity. A Student test was used to show if GSI varies from one year to another, if differences exist between immature and mature animals and between mature males and females. A F-test was used to highlight differences between GSI variances of mature males and females. Finally, a linear model was used to explore the correlation between mature males DML and GSI.

\section{RESULTS}

\section{Length frequency of samples}

Female specimens ranged from 6 to $27 \mathrm{~cm}$ DML in 2010 and from 7 to $26 \mathrm{~cm}$ DML in 2011. Male specimens ranged from 6 to $36 \mathrm{~cm}$ DML in 2010 and from 7 to $32 \mathrm{~cm}$ DML in 2011 (Fig. Erreur ! Source du renvoi introuvable.). Length frequencies highlighted that a first cohort was identifiable and the maximum size of this first cohort could be determined at $16 \mathrm{~cm}$ for both sexes in 2010 and at $14 \mathrm{~cm}$ and $13 \mathrm{~cm}$ for females and males respectively in 2011. In 2010, the smallest mature females were $7 \mathrm{~cm}$ long while the smallest mature males were $8 \mathrm{~cm}$ long. In 2011, the smallest mature females were $11 \mathrm{~cm}$ long and the smallest mature males were $10 \mathrm{~cm}$. In 2010, $17 \%$ of females and $30 \%$ of males assigned to the first cohort were found to be mature and in $2011,3 \%$ of females and $13 \%$ of males of the first cohort were found to be mature. For both years, sex ratios were significantly different from 1:1 with males more numerous than females, particularly in 2011.

Figure Erreur! Source du renvoi introuvable.

Size-at-maturity determined using a binomial error GLM

For both sexes, the size-at-maturity (Fig. Erreur ! Source du renvoi introuvable.) was higher in 2010 than in 2011 and for both years, size-at-maturity in females was larger than in males. For male specimens, the smallest length class within which all individuals were found 
to be mature was $16 \mathrm{~cm}$ DML in 2010 and $14 \mathrm{~cm}$ DML in 2011, above these length classes all male specimens were found to be mature. In contrast, for female specimens, the smallest length within which all individuals were found to be mature was smaller at $14 \mathrm{~cm}$ in 2010 and $13 \mathrm{~cm}$ in 2011, however, above these length classes, immature individuals were still found to occur.

Figure Erreur ! Source du renvoi introuvable.

Variability in lipofuscin measurement and age estimation

Lipofuscin measurement from the first experiment (Fig. Erreur ! Source du renvoi introuvable.) showed that, over a period of three days, no significant trend was observed in lipofuscin concentration; however, the standard deviation of the measure did increase with time. In the second experiment, lipofuscin accumulation measured in specimens belonging to the first and second cohorts were significantly different (Fig. Erreur ! Source du renvoi introuvable.). Results of the lipofuscin measurement performed on the 3 small mature males (Fig. Erreur! Source du renvoi introuvable., Table 1) highlighted that lipofuscin accumulation of these 3 specimens was not significantly different from the first cohort, but was significantly different from lipofuscin accumulation measured in GIIB. These 3 specimens could thus be considered as part of the GIB group.

\section{Figure Erreur ! Source du renvoi introuvable.}

Figure Erreur ! Source du renvoi introuvable.

Table 1

\section{Gonado-Somatic Index}

The GSI (Fig. Erreur ! Source du renvoi introuvable.) for each sex and each year, does not reveal inter-annual significant differences. For both sexes, the GSI during the reproduction period was significantly higher for mature specimens than for immatures. Mature female specimens were characterised by a significantly higher GSI and a higher inter-individual variability than mature males. Finally, the GSI of mature male specimens was found to be significantly-correlated with DML.

Figure Erreur ! Source du renvoi introuvable.

\section{DISCUSSION}

The life cycle of S. officinalis population in the English Channel was described in the past as lasting two years for females and the large majority of males (Boucaud-Camou et al., 1991; Dunn, 1999a). The present study highlights that, during 2010 and 2011 reproduction seasons, a variable percentage of mature male and female $S$. officinalis belongs to the first cohort and could be considered as a GIB. Age determination was based on polymodal decomposition and adaption of lipofuscin measurement protocol (Zielinski and Pörtner, 2000; Doubleday and Semmens, 2011). Both associated methods give more accurate than the polymodal decomposition used alone in previous studies and enabled to disentangle the two sampled cohorts. It has corroborated that the smallest mature animals observed are most likely one year old S. officinalis and not small two years olds. Finally, the GSI illustrates the amount of energy dedicated by each sex to the development of the gonad to the detriment of the somatic growth.

Lipofuscin measurement has helped in determining the cohort to which each specimen belongs, but this method is not accurate enough for age estimation (Zielinski and Pörtner, 2000; Doubleday and Semmens, 2011). Moreover, accuracy decreases with increasing time between death and sampling; as the sampling process was based on commercial fishery landings, this parameter is not under control. Finally, lipofuscin measurement is expensive and time consuming and for this reason experiments cannot be carried out on a large number of specimens. An alternative method for rough age estimation could be set up using statoliths. Although statolith daily rings are not accurately readable in one year old S. officinalis 
(Bettencourt and Guerra, 2001; Challier et al., 2002, 2006), studies of several fish species have found that otolith length, thickness and weight continued to grow with age even when body growth rate was null (Reznick et al., 1989; Campana, 1990; Newman, 2002). Age frequency distribution derived from otolith weights were found to be consistent with those derived from increment counts (Pilling et al., 2003; Mc Dougall, 2004). Moreover, statolith diameter has also been successfully used as a proxy of age in the planktonic tunicate Oikopleura vanhoeffeni (Choe and Deibel, 2009). If S. officinalis statolith experiences daily increments throughout its life, measuring dome diameters could be another way to separate the two annual cohorts.

In cephalopod species, rearing experiments have shown that maturation is driven by different factors including photoperiod, food availability and temperature (Mangold, 1987). Cephalopods are known not to store ingested energy in their tissues and as such individuals, particularly females, need a regular food availability in order to reach maturity as observed for Sepioteuthis australis (Ho et al., 2004) and Loligo vulgaris (Moreno et al., 2005). Thus, the variability observed in the female GSI and the sporadic presence of immature females belonging to the second cohort could be explained by food availability experienced by each specimen. In male specimens, the lower amount of energy dedicated to the reproduction lets more energy to somatic growth and therefore explains both the low variability of the GSI and a larger DML than in females. It is also worth noting that, within this study, the size-atmaturity plots for males are quite homogeneous and do not reveal subgroups maturing at different sizes as previously described for other cephalopod species (Coelho et al., 1994; Moreno et al., 1994; Boyle and Rodhouse, 2005). Finally, the English Channel warming (Hawkins et al., 2003; Saulquin and Gohin, 2010) leads to the modification of species communities by increasing abundance of warm water species and decreasing abundance of cold water species. Such modifications could also influence the English Channel population of S. officinalis by modifying the competition and the predator-prey relationships.

Temperature is a key parameter influencing cephalopod life cycles, from egg development to reproduction (Rodhouse et al., 1992; Boyle and Pierce, 1994). An increase in environmental temperature generally accelerates the somatic growth of cephalopod, shortening the life cycle duration by accelerating maturation (Moreno et al., 2007). This is a well known feature in the life cycle of $S$. officinalis which shortens from the north of its distribution area (English Channel) to the south (West African coasts ; Mangold, 1966; Guerra and Castro, 1988; Coelho and Marthins, 1991). The warming of the English Channel (Hawkins et al., 2003; Saulquin and Gohin, 2010) could be the cause of appearance of a GIB made of males and females and the observation of a lower size-at-maturity (on average $12.16 \mathrm{~cm}$ for males and $12.41 \mathrm{~cm}$ for females in 2010 and 2011 respectively) than that observed by Dunn (1999a) (14.6 cm for males and $16.4 \mathrm{~cm}$ for females). Further investigations are required to investigate if this sizeat-maturity variability could be correlated with environmental indices (such as NAO index) and wether GIB is actually involved in reproduction by analysing the sperm reservoirs of female to understand wether cross-mating between generations exists (Gauvrit et al., 1998). Warming of the English Channel could also lead to an extension of the reproduction season allowing the more precocious hatchlings sufficient time to mature prior to the following spring.

In S. officinalis population of the English Channel, Challier et al. (2006) showed that recruitment in the trawling fishery occurs throughout the year at a constant age leading to the conclusion that $S$. officinalis hatches throughout the year. GIB observed in this study could thus be individuals which had hatched early in the reproduction and which had had enough time before offshore migration to start maturation and finish it before the end of next spring.

The English Channel has long been exploited by both French and UK fishers. Trawling started 200 years ago and fishing pressure has regularly increased since the beginning of the 
twentieth century (Hawkins et al., 2003; Guenette and Gascuel, 2012; Gras, 2013). High fishing pressure greatly impacts demersal communities and can modify life history traits by favouring specimens which mature faster or reach maturity at a smaller size or lower age (Shin et al., 2005; Kantoussan et al., 2009). This phenomenon has been observed in a range of N-E Atlantic stocks (Shin and Rochet, 1998; Grift et al., 2003; Engelhard and Heino, 2004; Olsen et al., 2004) and could also have influenced the English Channel population of S. officinalis, which is fully exploited since the beginning the 1990s (Royer et al., 2006; Gras et al., 2014), leading to the appearance of a GIB and a potential decreasing trend in size-at-maturity. Modifications in demersal community assemblages caused by high fishing pressure could have modify the prey availability for cuttlefish. Maturation efficiency in cephalopods, which are unable to store energy in their tissue (Mangold, 1987; Moreno et al., 2005) could therefore be impacted.

S. officinalis is one of the top predators of the English Channel ecosystem. In contrast to other top predators, S. officinalis has a short lifespan and as such, the consequences of any regime shift can be easily observed in the short term and could thus provide a useful indicator of climate change. According to Jackson et al. (2000), an indicator of climate change must meet 4 criteria : (i) relevance to assessment and ecological functions, (ii) feasibility of data collection, (iii) response to variation and (iv) interpretation and utility of data to highlight the changing environment. Although S. officinalis is a non quota species (Pierce et al., 2010), 2 scientific bottom trawl surveys sample it each year (Carpentier et al., 2009) and maturity stages can be easily determined using the international WKMSCEPH scale (ICES, 2010). This could be complemented by data collected at landing sites throughout the year under the framework of the Data Collection Framework (DCF) programme. S. officinalis therefore meets the 4 criteria listed above and should be considered as an indicator for environmental shift.

\section{Acknowledgement}

The study was carried out under the EU funded project "CRESH" (under the Interreg IV A France-Manche-England programme). We thank Jehane Lepoittevin, Said Slimane-Moussa, Olivier Goetz and Florentin Bezin for their participation in dissecting the samples and Beatrice Adeline for the tissue preparation.

\section{References}

Beaugrand, G. (2009). Decadal changes in climate and ecosystems in the North Atlantic Ocean and adjacent seas. Deep Sea Research Part II: Topical Studies in Oceanography, 56(8-10):656-673.

Beaugrand, G. and Reid, P. C. (2003). Long-term changes in phytoplankton, zooplankton and salmon related to climate. Global Change Biology, 9(6):801-817.

Bettencourt, V. and Guerra, A. (2001). Age studies based on daily growth increments in statoliths and growth lamellae in cuttlebone of cultured Sepia officinalis. Marine Biology, 139(2):327-334.

Bianchi, G., Gislason, H., Graham, K., Hill, L., Jin, X., Koranteng, K., ManickchandHeileman, S., Payá, I., Sainsbury, K., Sanchez, F., and Zwanenburg, K. (2000). Impact of fishing on size composition and diversity of demersal fish communities. ICES Journal of Marine Science, 57(3):558-571.

Bluhm, B. A. and Brey, T. (2001). Age determination in the Antarctic shrimp Notocrangon antarcticus (Crustacea: Decapoda), using the autofluorescent pigment lipofuscin. Marine Biology, 138(2):247-257.

Boletzky, S. (1983). Sepia officinalis. In Boyle, P. R., editor, Cephalopod Life Cycles vol 1. Species Accounts, pages 31-52. Academic Press, London, UK. 
Boucaud-Camou, E. and Boismery, J. (1991). The migrations of the cuttlefish (Sepia officinalis L.) in the English Channel. In Boucaud-Camou, E., editor, La Seiche / The Cuttlefish, pages 179-189, Caen, France. Centre de publication de l'Université de Caen. Boucaud-Camou, E., Koueta, N., Boismery, J., and Medhioub, A. (1991). The sexual maturity of Sepia officinalis L. from the Bay of Seine. In Boucaud-Camou, E., editor, La Seiche / The Cuttlefish, pages 141-151, Caen, France. Centre de publication de l’Université de Caen. Boyle, P. R. and Pierce, G. J. (1994). Fishery biology of the Northeast Atlantic squid. Fisheries Research, 21(1-2):1-314.

Boyle, P. R. and Rodhouse, P. G. (2005). Cephalopods: Ecology and Fisheries. John Wiley, New York, USA.

Campana, S. E. (1990). How Reliable are Growth Back-Calculations Based on Otoliths? Canadian Journal of Fisheries and Aquatic Sciences, 47(11):2219-2227.

Carpentier, A., Martin, C. S., and Vaz, S. (2009). Channel Habitat Atlas for marine Resource Management, final report / Atlas des Habitats des Ressources Marines de la Manche Orientale CHARM II. Boulogne-sur-Mer, France.

Challier, L., Dunn, M. R., and Robin, J.-p. (2005). Trends in age-at-recruitment and juvenile growth of cuttlefish, Sepia officinalis, from the English Channel. ICES Journal of Marine Science, 62(8):1671-1682.

Challier, L., Pierce, G. J., and Robin, J.-P. (2006). Spatial and temporal variation in age and growth in juvenile Loligo forbesi and relationships with recruitment in the English Channel and Scottish waters. Journal of Sea Research, 55(3):217-229.

Challier, L., Royer, J., and Robin, J.-P. (2002). Variability in age-at-recruitment and early growth in English Channel Sepia officinalis described with statolith analysis. Aquatic Living Resources, 15(5):303-311.

Choe, N. and Deibel, D. (2009). Statolith diameter as an age indicator in the planktonic tunicate Oikopleura vanhoeffeni: Variability in age-specific growth patterns in Conception Bay, Newfoundland. Journal of Experimental Marine Biology and Ecology, 375(1-2):89-98. Coelho, M. L. and Marthins, M. C. (1991). Preliminary observations on the biology of Sepia officinalis in Ria Formosa, Portugal. In Boucaud-Camou, E., editor, La Seiche / The Cuttlefish, pages 131-140. Centre de Publications de l’Université de Caen, Caen, France.

Coelho, M. L., Quintela, J., Bettencourt, V., Olavo, G., and Villa, H. (1994). Population structure, maturation patterns and fecundity of the squid Loligo vulgaris from southern Portugal. Fisheries Research, 21(1-2):87-102.

Doubleday, Z. A. and Semmens, J. M. (2011). Quantification of the age-pigment lipofuscin in known-age octopus (Octopus pallidus): A potential tool for age determination. Journal of Experimental Marine Biology and Ecology, 397(1):8-12.

Dunn, M. R. (1999a). Aspects of the stock dynamics and exploitation of cuttlefish, Sepia officinalis (Linnaeus, 1758), in the English Channel. Fisheries Research, 40(3):277-293. Dunn, M. R. (1999b). The exploitation of selected non-quota species in the English Channel. $\mathrm{PhD}$ thesis, University of Portsmouth.

Engelhard, G. and Heino, M. (2004). Maturity changes in Norwegian spring-spawning herring Clupea harengus: compensatory or evolutionary responses? Marine Ecology Progress Series, 272:245-256.

Gauvrit, E., Le Goff, R., and Daguzan, J. (1997). Reproductive cycle of the cuttlefish, Sepia officinalis (L.) in the northern part of the Bay of Biscay. Journal of Molluscan Studies, 63(1):19-28.

Gauvrit, E., Pinczon du Sel, G., Blanc, A., and Daguzan, J. (1998). Detection of cross-mating between two generations of the cuttlefish Sepia officinalis by sperm reservoir analysis.

Journal of Molluscan Studies, 64(1):1-9.

Gras, M. (2013). Contribution des frayères côtières au recrutement du stock de seiche Sepia 
officinalis de Manche : lien entre le succès de la phase pré-recrutée et l'abondance de la ressource. Phd, University of Caen Lower-Normandy.

Gras, M., Roel, B. A., Coppin, F., Foucher, E., and Robin, J.-P. (2014). A two-stage biomass model to assess the English Channel cuttlefish (Sepia officinalis L.) stock. ICES Journal of Marine Science.

Grift, R. E., Rijnsdorp, A. D., Barot, S., Heino, M., and Dieckmann, U. (2003). Fisheriesinduced trends in reaction norms for maturation in North Sea plaice. Marine Ecology Progress Series, 257:247-257.

Guenette, S. and Gascuel, D. (2012). Shifting baselines in European fisheries: The case of the Celtic Sea and Bay of Biscay. Ocean \& Coastal Management, 70(1):10-21.

Guerra, A. and Castro, B. G. (1988). On the life-cycle of Sepia officinalis in the Ria de Vigo. Cahiers de Biologie Marine, 29:395-405.

Hawkins, S. J., Southward, A. J., and Genner, M. J. (2003). Detection of environmental change in a marine ecosystem-evidence from the western English Channel. The Science of the total environment, 310(1-3):245-56.

Hill, K. T. and Womersley, C. (1991). Critical aspects of fluorescent age-pigment methodologies: Modification for accurate analysis and age assessments in aquatic organisms. Marine Biology, 109(1):1-11.

Ho, J. D., Moltschaniwskyj, N. A., and Carter, C. G. (2004). The effect of variability in growth on somatic condition and reproductive status in the southern calamary Sepioteuthis australis. Marine and Freshwater Research, 55(4):423.

ICES (2010). Report of the Workshop on Sexual Maturity Staging of Cephalopods (WKMSCEPH). ICES CM 2010/ACOM:49. Technical report, ICES, Livorno, Italy. Jackson, L. E., Kurtz, J. C., and Fisher, W. S. (2000). Evaluation guidelines for ecological indicators. EPA/620/R-99/005. Technical Report May, U.S. Environmental Protection Agency, Office of Research and Development, Research Triangle Park, NC.

Ju, S. J., Secor, D. H., and Harvey, H. R. (1999). Use of extractable lipofuscin for age determination of blue crab Callinectes sapidus. Marine Ecology Progress Series, 185(1):171179.

Kantoussan, J., Ecoutin, J.-M., Fontenelle, G., Thiaw, O. T., Tito de Morais, L., and Lae, R. (2009). The relevance of size parameters as indicators of fishery exploitation in two West African reservoirs. Aquatic Ecology, 43:1167-1178.

Le Goff, R. and Daguzan, J. (1991). Growth and life cycles of the cuttlefish Sepia officinalis

L. (Mollusca: Cephalopoda) in South Brittany (France). Bulletin of Marine Science, 49(12):341-348.

Le Goff, R., Gauvrit, E., Pinczon du Sel, G., and Daguzan, J. (1998). Age group determination by analysis of the cuttlebone of the cuttlefish Sepia officinalis L . in reproduction in the Bay of Biscay. Journal of Molluscan Studies, 64(2):183-193.

Mangold (1987). Reproduction. In Boyle, P. R., editor, Cephalopod life cycles vol 2.

Comparative review, pages 157-200. Academic Press, London, UK.

Mangold, K. (1966). Sepia officinalis de la mer Catalane. Vie Et Milieu - Life and

Environment, 17:961-1012.

Mc Dougall, A. (2004). Assessing the use of sectioned otoliths and other methods to determine the age of the centropomid fish, barramundi (Lates calcarifer) (Bloch), using known-age fish. Fisheries Research, 67(2):129-141.

Moreno, A., Azevedo, M., Pereira, J. a., and Pierce, G. J. (2007). Growth strategies in the squid Loligo vulgaris from Portuguese waters. Marine Biology Research, 3(1):49-59.

Moreno, A., Cunha, M. M., and Pereira, J. a. M. F. (1994). Population biology of veined squid (Loligo forbesi) and European Squid (Loligo vulgaris) from the Portuguese coast. Fisheries Research, 21(1-2):71-86. 
Moreno, A., Pereira, J. a., and Cunha, M. (2005). Environmental influences on age and size at maturity of Loligo vulgaris. Aquatic Living Resources, 18(04):377-384.

Newman, S. J. (2002). Growth rate, age determination, natural mortality and production potential of the scarlet seaperch, Lutjanus malabaricus Schneider 1801, off the Pilbara coast of north-western Australia. Fisheries Research, 58(2):215-225.

Olsen, E. M., Heino, M., Lilly, G. R., Morgan, M. J., Brattey, J., Ernande, B., and Dieckmann, U. (2004). Maturation trends indicative of rapid evolution preceded the collapse of northern cod. Nature, 428:932-935.

Pierce, G. J., Allcock, L., Bruno, I., Bustamante, P., González, A. F., Guerra, A., Jereb, P., Lefkaditou, E., Malham, S., Moreno, A., Pereira, J. a., Piatkowski, U., Rasero, M., Sánchez, P., Santos, M. B. n., Santurtún, M., Seixas, S., Sobrino, I., and Villanueva, R. (2010). Cephalopod biology and fisheries in Europe. Technical report, ICES Cooperative Research Report n 303, Copenhagen.

Pilling, G., Grandcourt, E. M., and Kirkwood, G. P. (2003). The utility of otolith weight as a predictor of age in the emperor Lethrinus mahsena and other tropical fish species. Fisheries Research, 60(2-3):493-506.

Pingree, R. D. (1980). Chapter 13 Physical oceanography of the Celtic Sea and English Channel. In Banner, F. T., Collins, M. B., and Massie, K. S., editors, The North-West European Shelf Seas: the Sea Bed and the Sea in Motion 2. Physical and Chemical Oceanography, and Physical Resources, volume 24, Part B of Elsevier Oceanography Series, pages 415-465. Elsevier, Amsterdam.

Portail CHARM III - Interreg IV, (O). (2012). Atlas des pêcheries de Manche, Channel fisheries atlas. Engelhard G., Vignot C., Leblond E., Lesueur M., Guitton J. http://charmproject.org/fr/outils/atlas-des-pecheries/atlas-des-pecheries-outils.

Reznick, D., Lindbeck, E., and Bryga, H. (1989). Slower growth results in larger otoliths: an experimental test with guppies (Poecilia reticulata). Canadian Journal of Fisheries and Aquatic Sciences, 46(1):108-112.

Rodhouse, P. G., Symon, C., and Hatfield, E. M. C. (1992). Early life cycle of cephalopods in relation to the major oceanographic features of the southwest Atlantic Ocean. Marine Ecology Progress Series, 89:183-195.

Royer, J., Pierce, G. J., Foucher, E., and Robin, J.-P. (2006). The English Channel stock of Sepia officinalis: Modelling variability in abundance and impact of the fishery. Fisheries Research, 78(1):96-106.

Saulquin, B. and Gohin, F. (2010). International Journal of Remote Mean seasonal cycle and evolution of the sea surface temperature from satellite and in situ data in the English Channel for the period 1986 - 2006. International Journal of Remote sensingensing, 31(15):40694093.

Sheehy, M. R. J., Shelton, P. M. J., Wickins, J. F., Belchier., M., and Gaten, E. (1996). Ageing the European lobster Homarus gammarus by the lipofuscin in its eyestalk ganglia. Marine Ecology Progress Series, 143(1):99-111.

Shin, Y.-J. and Rochet, M.-J. (1998). A model for the phenotypic plasticity of North Sea herring growth in relation to trophic conditions. Aquatic Living Resources, 11(05):315-324. Shin, Y.-J., Rochet, M.-J., Jennings, S., Field, J. G., and Gislason, H. (2005). Using size-based indicators to evaluate the ecosystem effects of fishing. ICES Journal of Marine Science, 62(3):384-396.

Smith, P. J. (1994). Genetic diversity of marine fisheries resources. Possible impacts of fishing. FAO Fisheries Technical Paper No. 344, Rome, Italy.

Southward, A. J., Boalch, G. T., and Maddock, L. (1988). Fluctuations in the herring and pilchard fisheries of devon and cornwall linked to change in climate since the 16 century. Journal of the Marine Biological Association of the United Kingdom, 68(03):423-445. 
Southward, A. J. and Roberts, E. K. (1987). One hundred years of marine research at Plymouth. Journal of the Marine Biological Association of the UK, 67(3):465-506.

Wang, J., Pierce, G. J., Boyle, P. R., Denis, V., Robin, J.-P., and Bellido, J. M. (2003). Spatial and temporal patterns of cuttlefish (Sepia officinalis) abundance and environmental influences - a case study using trawl fishery data in French Atlantic coastal, English Channel, and adjacent waters. ICES Journal of Marine Science, 60(03):1149-1158.

Zielinski, S. and Pörtner, H.-O. (2000). Oxidative stress and antioxidative defense in cephalopods : a function of metabolic rate or age? Comparative Biochemistry and Physiology Part B, 125:147-160.

Table 1: Probabilities of 3 small male mature specimens to be different from the GIB and GIIB cohorts.

\begin{tabular}{llll}
\hline \hline Specimens & Length $(\mathrm{cm})$ & P-value, GIB & P-value, GIIB \\
\hline First cohort (immature ; 11 specimens) & $10<\mathrm{L}<13$ & & \\
Second cohort (mature ; 17 specimens) & $20<\mathrm{L}<31$ & & \\
Individual 1 & 11 & 0.12 & 0.02 \\
Individual 2 & 11 & 0.08 & 0.03 \\
Individual 3 & 13 & 0.22 & 0.02 \\
\hline \hline
\end{tabular}

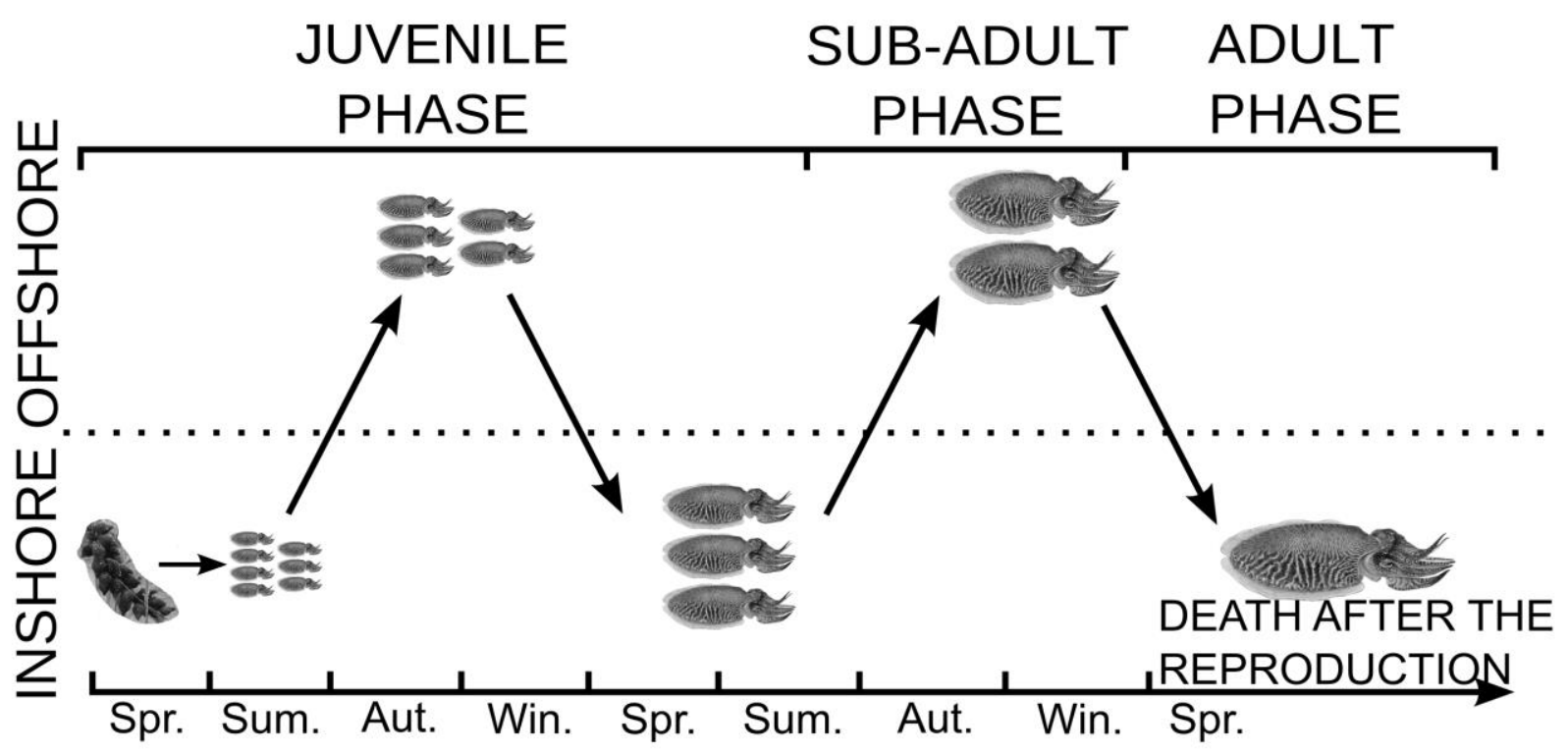

Figure 1: Life cycle of the English Channel population of S. officinalis S. officinalis L. as described by Boucaud-Camou and Boismery (1991), Boucaud-Camou et al. (1991) and Dunn (1999a). 




Figure 2: Length frequencies of the female and male samples collected during springs 2010 and 2011 in French English Channel landing sites. Immature specimens are displayed in white and mature specimens are displayed in grey. The vertical line drawn 


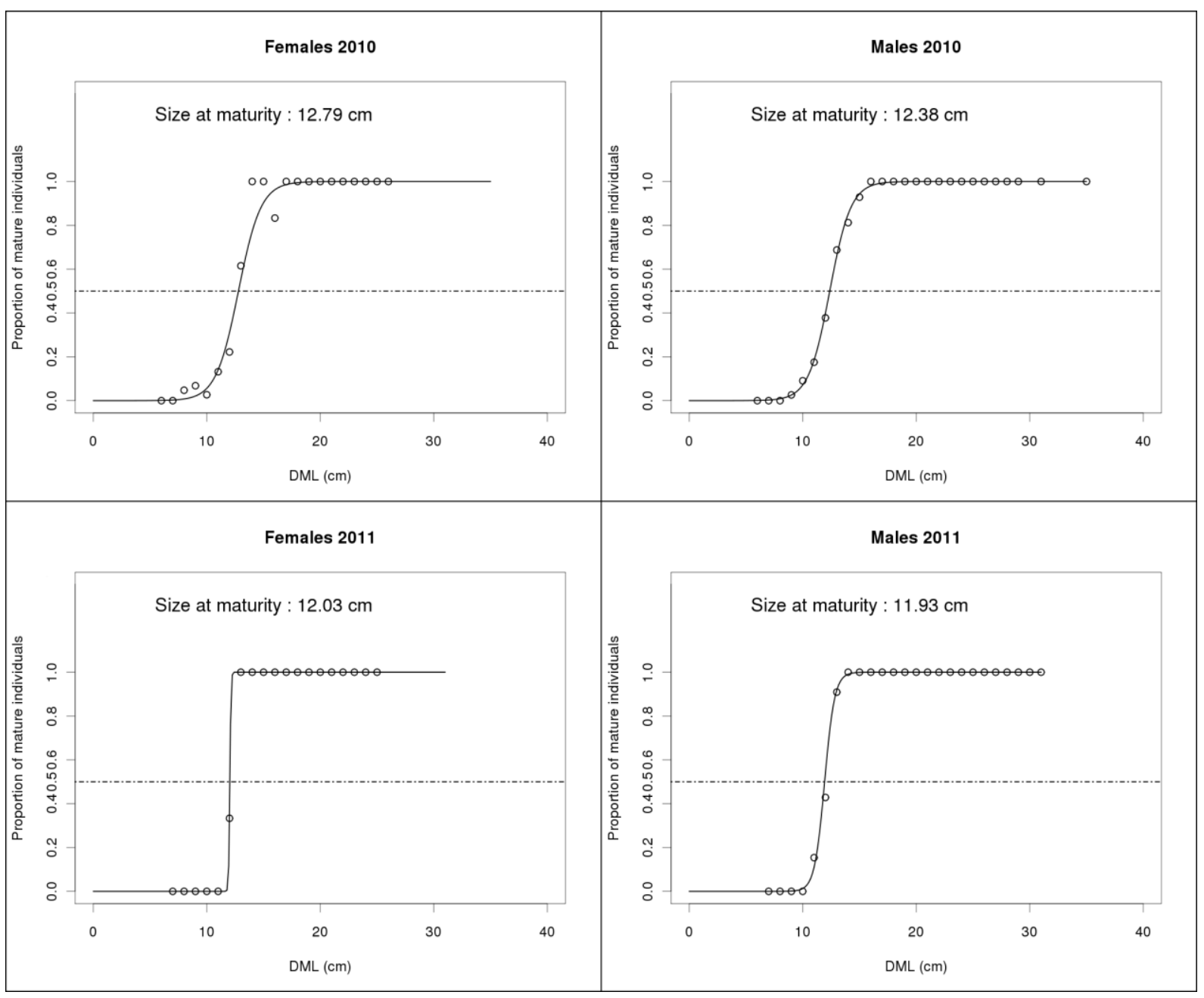

Figure 3: Size-at-maturity determined using a binomial error GLM for female and male samples collected during springs 2010 and 2011 in French English Channel landing sites. The $95 \%$ confidence interval of the fitted binomial error GLM is displayed with dashed lines. Number of specimens measured per DML class is pointed out in the figure Erreur ! Source du renvoi introuvable. 


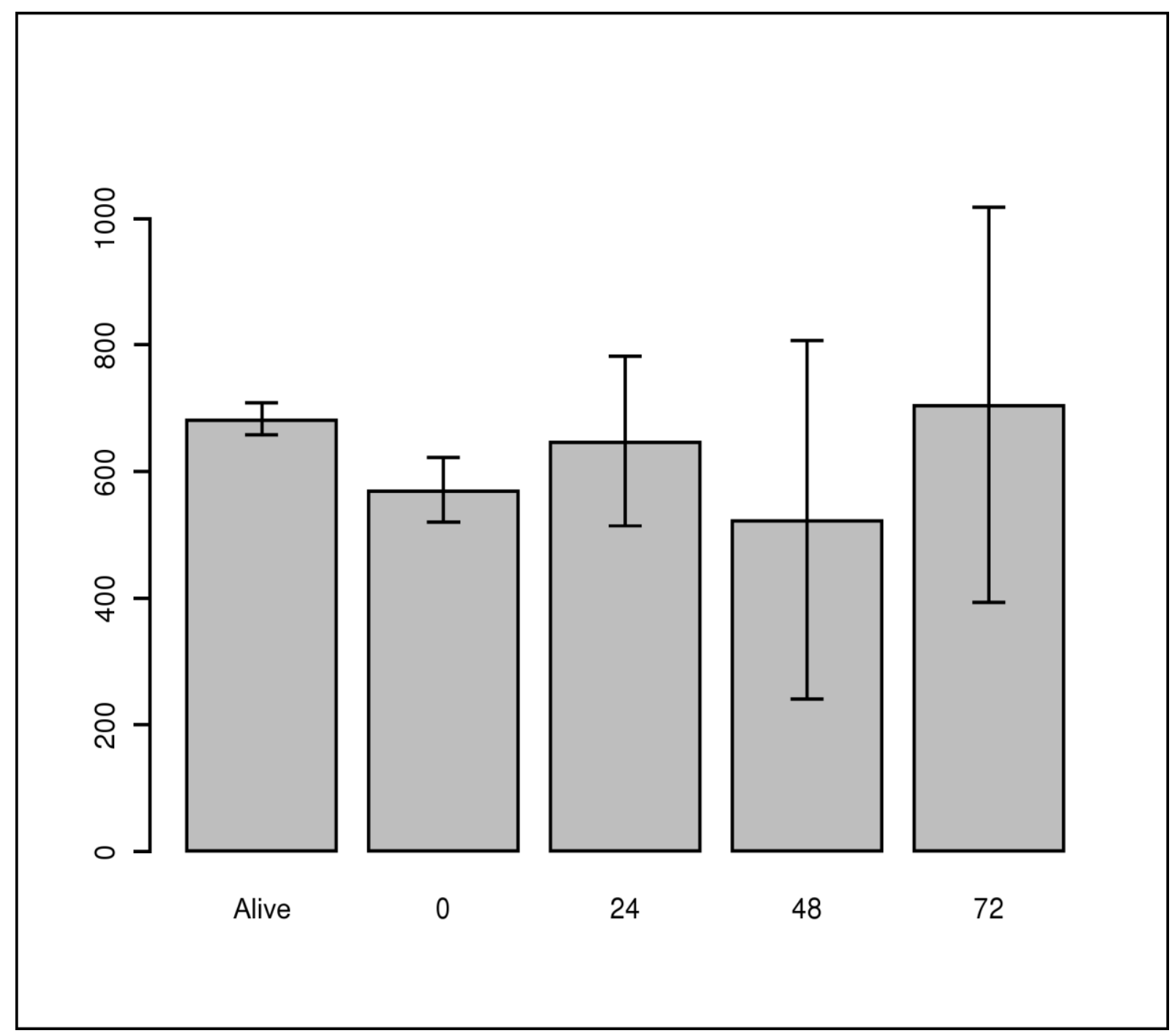

Figure 4: Trend in lipofuscin concentration measured in the mantle sampled on one living $S$. officinalis from the death and every 24 hours until 72 hours after the death. Error bars are the standard deviations of each measure. Number of measures performed at each time step is mentioned between brackets. 


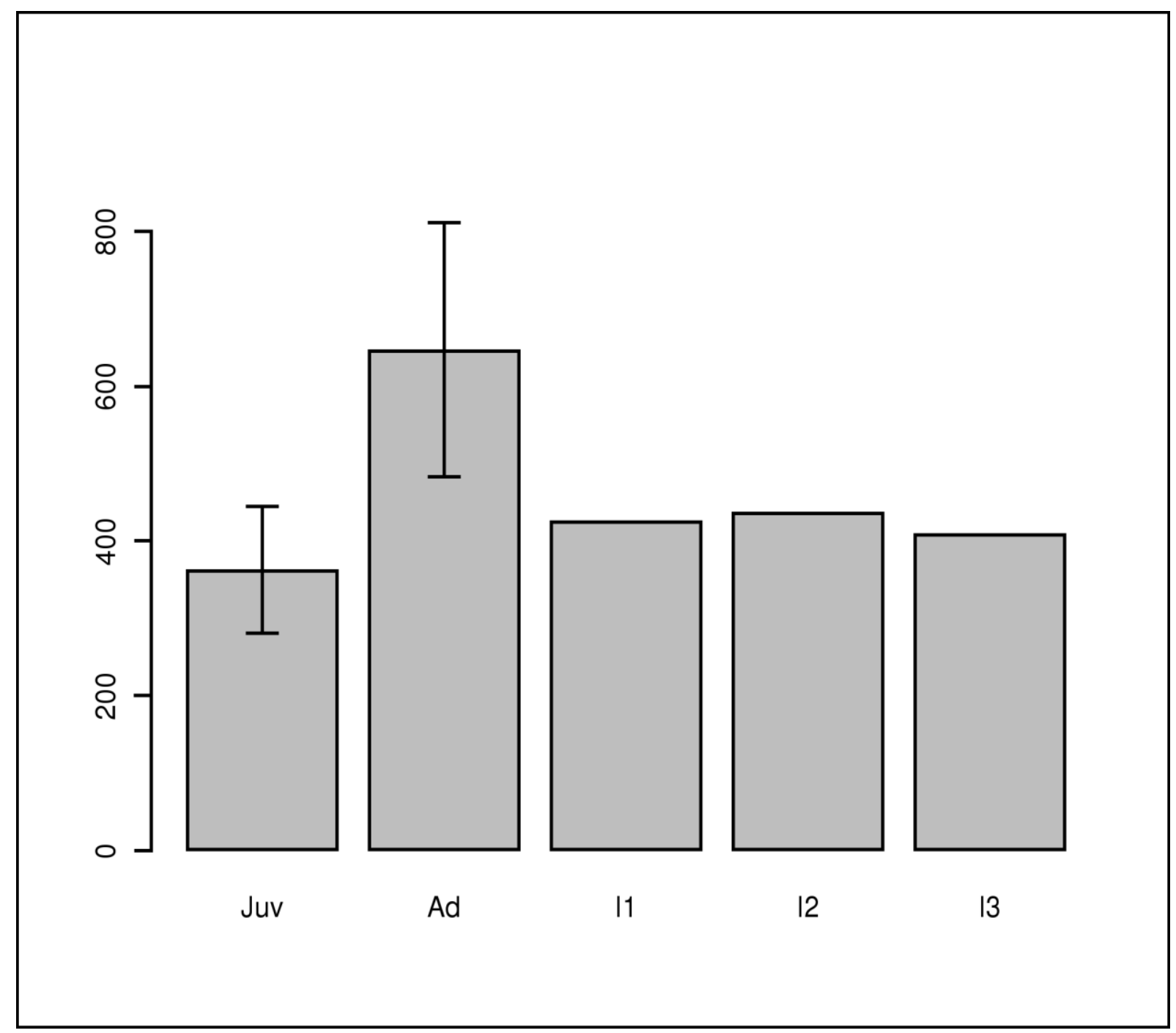

Figure 5: Lipofuscin concentration measured in S. officinalis mantles for juveniles (Juv, 11 specimens, ranging 10-13 cm DML ), Adults (Ad, 17 specimens, ranging 20-31 cm DML) with the inter-individual standard deviation and lipofuscin concentration measured in 3 small mature specimens (I1, $11 \mathrm{~cm}$ DML; I2 $11 \mathrm{~cm}$ DML; I3, $13 \mathrm{~cm}$ DML). 


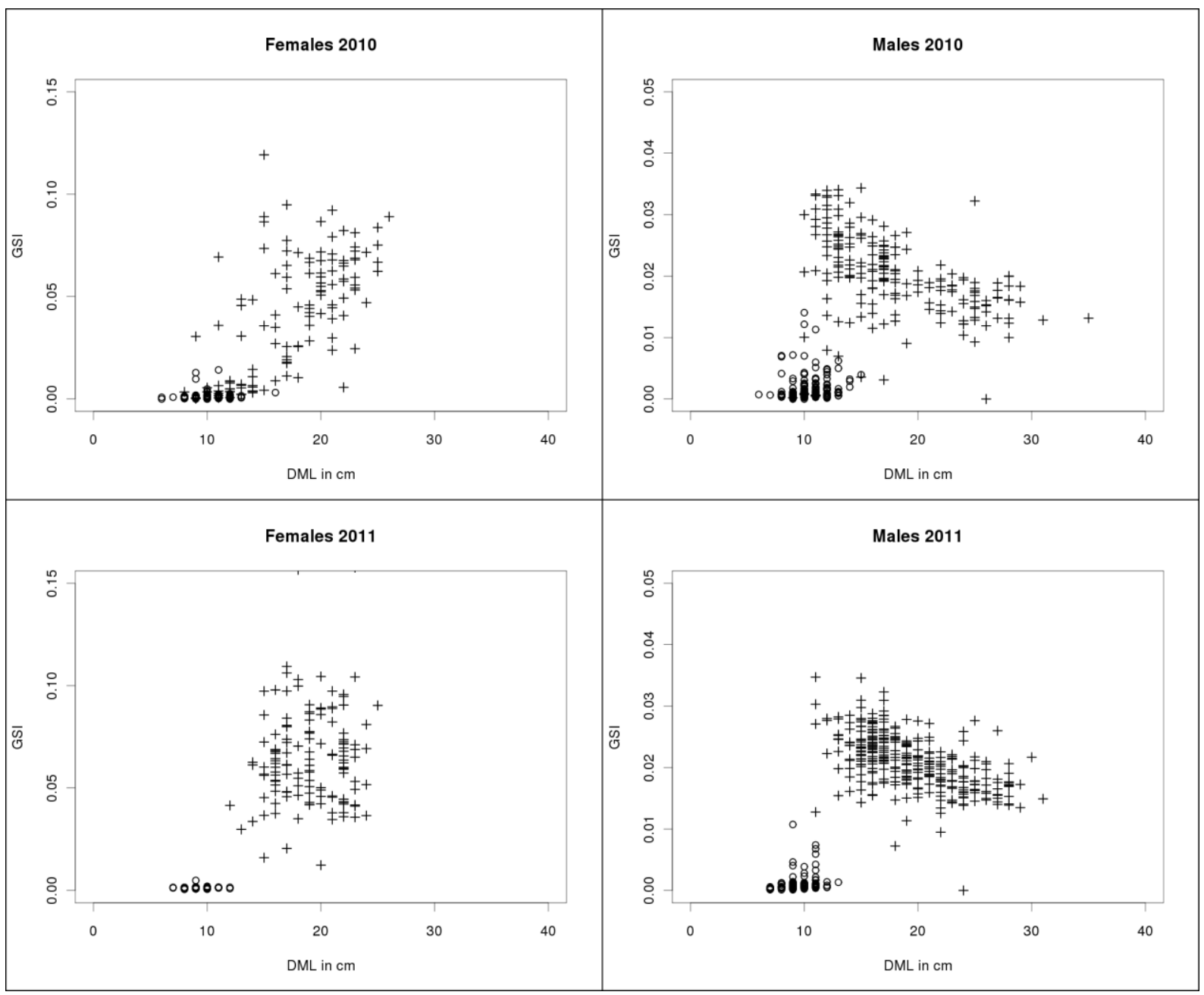

Figure 6: Gonado Somatic Index (GSI) vs Dorsal Mantle Length (DML) for female and male samples collected during springs 2010 and 2011 in French English Channel landing sites. Immature specimens are displayed with circles while mature specimens are displayed with crosses. 